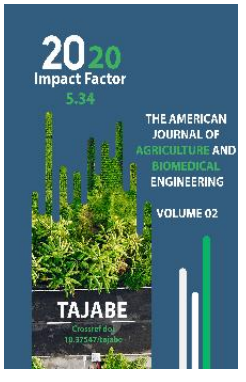

Journal Website: http://usajournalshub.c om/index,php/tajabe

Copyright: Original content from this work may be used under the terms of the creative commons attributes 4.0 licence.

\section{Determination Of The Quality Mark Of The Goose In The Cultivation Of Elite Seeds And Their Adaptation To International Requirements}

\author{
Kozubaev Shukhrat Sattardjanovich \\ Ph.D., Professor, Republic Of Uzbekistan, Research Institute Of Cotton Breeding, Seed \\ Production And Agrotechnology, Uzbekistan. \\ Abduvoxidov Giyos Kurbanalievich \\ 2nd Stage Basic Doctoral Student, Republic Of Uzbekistan, Research Institute Of Cotton \\ Breeding, Seed Production And Agrotechnology, Uzbekistan. \\ Rasulov Dilmurod Ibodullaevich \\ 1st Stage Basic Doctoral Student, Republic Of Uzbekistan, Research Institute of Cotton \\ Breeding, Seed Production And Agrotechnology, Uzbekistan. \\ Abdurahmanova Nodira Daniyarovna \\ Junior Researcher, Republic Of Uzbekistan, Research Institute Of Cotton Breeding, Seed \\ Production And Agrotechnology, Uzbekistan.
}

\title{
ABSTRACT
}

This article indicates that farmers and clusters of the republic need to pay special attention to sowing qualities when preparing seed material. Currently used standards do not meet current requirements, where they offer solutions to this problem.

\section{KEYWORDS}

Cotton, seeds, elite seeds, first generation seeds, second generation seeds, third generation seeds, fertility, 1000 seed weight, ISTA.

\section{INTRODUCTION}

On October 23, 2019, President of the Republic of Uzbekistan Shavkat Mirziyoyev signed a Decree "On approval of the Strategy of agricultural development of the Republic of
Uzbekistan for 2020-2030." Ensuring food security of the population in this Strategy, which is expected to make a radical turn in the agricultural sector of the country; creating a favorable agribusiness environment and value chain; reduction of state participation in the 
management of the sector and increase of investment attractiveness; rational use of natural resources and protection of the environment; development of modern management systems; gradual diversification of public spending to support the sector; development of the system of science, education, information and consulting services in agriculture; rural development; 9 priority areas of agricultural development of the country have been identified, such as the creation of a transparent system of sectoral statistics.

Cotton growing in Uzbekistan has a long history, and today our country is in the top ten among more than 80 cotton-growing countries in the world in many indicators (area under cotton, production volume, productivity).

Selection and seed production are organized as a single continuous process. In world practice, the author of the variety is engaged in seed production. For example, in the United States, a field or plot of land stocked and registered (sufficient for planting) is 1,320 feet (30.5 cm per foot) from a field of similar variety, and 2,640 feet +20 additional protected rows from a field of other varieties. should be separated by.

\section{MATERIALS AND METHODS}

In order to operate the seed system based on the varietal renewal scheme in the production of elite seeds, it is necessary to provide highquality elite seeds with the following. Bunda;

- maintenance of valuable economic and biological properties included in the state register and used in production;

- storage of pure varieties, self-pollinating crops, varieties or biological and mechanical pollution from external pollination, removal of species and varieties;

- Chemical treatment of seeds and planting material from fungal, bacterial and viral diseases with the use of biotechnological methods of sampling;

- improvement of high sowing qualities and productivity of seeds by modification method;

- Rapid propagation of seeds of new varieties for new renewal;

- organization of the seed insurance fund and the volume of the seed fund left for the following years, fulfillment of the production plan and sale (distribution) of elite seeds;

- increase the potential conditions for the creation of new and improve future methods;

Elite - the methods used in seed production do not always allow to quickly solve the problem of stabilization of the newly obtained selection item on the set of characteristics. In addition, a selective focus on multiple traits, excluding other traits, leads to a deterioration of other traits that are important to the variety when negative correlations are present.Environmental diversity plays an important role in the production of high quality seeds. This is because seed yield and quality often depend on soil-climatic conditions and the agronomic techniques used. Seed formation conditions affect changes in its chemical composition and physiological properties. Therefore, in different soil-climatic conditions, seeds grown on the basis of different cultivation technologies will have different physiological, crop and yield qualities.

\section{DISCUSSION AND ACKNOWLEDGEMENTS}

Maintaining quality indicators in the process of propagation and use of varietal seeds is the 
main content of seed production. Today, a number of key indicators are used to determine seed quality. In this case, the seed:

- determination of growth potential;

- determination of forgetfulness;

- determination of the level of pollution;

- detection of mechanical damage;

- detection of warehouse pests;

- determination of humidity;

-Determination of the weight of 1000 seeds:

SeedsOzDst 663: 2017 "Seeds. Specifications "meets the requirements of the state standard. This is a gratifying situation, of course, but there is much more scientific and practical work to be done. For example, the degree of mechanical damage to seeds is the norm, with a maximum of $7 \%$ for hairy seeds and $8 \%$ for hairless seeds. However, if we look at the international ISTA requirement, they recommend that this figure should not exceed $12 \%$ as supply rather than demand. In addition, the degree of damage was defined as strong, medium, and weak, i.e., the degree of mechanical damage to the field germination of seeds proved to be negligible. On the contrary, the lack of serious attention to these international standards leads to a number of inconveniences in seed certification.
The degree of mechanical damage, brought by the laboratory "Cotton Seed and Seed Production" of the Research Institute of Cotton Breeding, Seed Production and Agrotechnology from various ginneries, UzDst 663: 2017 "Seeds. The following results were obtained when sowing lots of seeds, which are much higher than the norms specified in the "Technical conditions" (Table 1).

Currently, the International Seed Quality Control Association (ISTA) recommends the following. Increase the number of working samples from two to four, have 100 seeds in each sample, use the names of the samples used in ISTA recommendations, ie first sample and composition sample, sample submitted for analysis, working sample, determine the growth rate and yield according to international recommendations. .

Becoming a member of the International Seed Quality Control Association (ISTA), the International Union for the Protection of Varieties (UPOV) and the Organization for Economic Cooperation and Development (OECD) to enter the world seed market by introducing new varieties included in the State Register in accordance with international standards.

Table 1 
Doi: https://doi.org/10.37547/tajabe/Volume02Issue09-05

\begin{tabular}{|c|c|c|c|c|c|c|c|c|c|c|c|c|c|c|c|c|c|}
\hline \multirow{3}{*}{$\begin{array}{l}21 \\
n \\
0 \\
0 \\
0 \\
\end{array}$} & \multirow{3}{*}{ 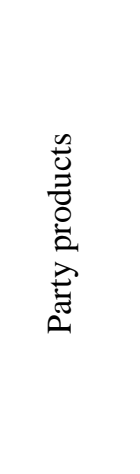 } & \multirow{3}{*}{ 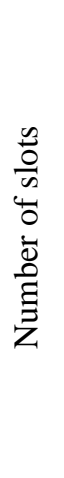 } & \multirow{3}{*}{$\begin{array}{l}\vec{D} \\
\tilde{D} \\
\tilde{n}\end{array}$} & \multirow{2}{*}{\multicolumn{2}{|c|}{ 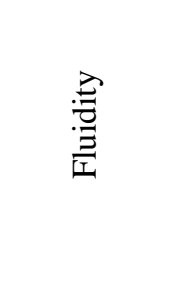 }} & \multirow{2}{*}{\multicolumn{2}{|c|}{$\begin{array}{l}y \\
\ddot{U} \\
z\end{array}$}} & \multicolumn{2}{|c|}{$\begin{array}{l}\overline{0} \\
8 \\
0 \\
0 \\
0\end{array}$} & \multicolumn{2}{|c|}{ 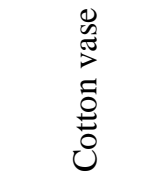 } & \multicolumn{2}{|c|}{$\stackrel{\tilde{\theta}}{\tilde{n}}$} & \multirow{2}{*}{\multicolumn{2}{|c|}{ 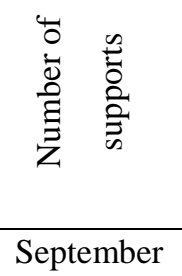 }} & \multicolumn{2}{|c|}{ 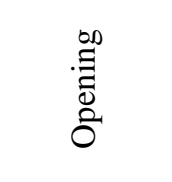 } \\
\hline & & & & & & & & $\mathrm{Se}_{1}$ & mber & & & & & & & Sept & mber \\
\hline & & & & 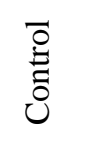 & : & 栉 & 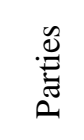 & $\begin{array}{l}\dot{0} \\
\dot{0}\end{array}$ & $\stackrel{\mathscr{Q}}{\stackrel{\mathscr{E}}{E}}$ & $\begin{array}{l}\bar{O} \\
\bar{\Xi} \\
\dot{0}\end{array}$ & . & $\begin{array}{l}\text { ö } \\
\text { : }\end{array}$ & $\stackrel{\mathscr{n}}{\stackrel{0}{\pi}}$ & 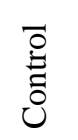 & $\stackrel{\mathscr{e}}{\stackrel{\mathscr{E}}{\vec{d}}}$ & $\begin{array}{l}\overline{0} \\
\overline{0}\end{array}$ & : \\
\hline 1 & $\begin{array}{c}\mathrm{P}-26 \\
(\mathrm{C}-6524)\end{array}$ & 20 & 5 & 65.0 & 60.0 & 111.2 & 106.7 & 15.6 & 14.9 & 3.05 & 3.0 & 5.2 & 4.8 & 17.2 & 16.8 & 0.65 & 0.75 \\
\hline 2 & $\begin{array}{c}\mathrm{P}-56 \\
(\mathrm{C}-6524)\end{array}$ & 20 & 5 & 68.0 & 61.3 & 109.0 & 106.7 & 15.6 & 15.3 & 3.4 & 3.6 & 5.0 & 5.13 & 17.3 & 15.6 & 0.8 & 0.6 \\
\hline 3 & $\begin{array}{c}\text { P-95 } \\
\text { (Sultan) }\end{array}$ & 20 & 5 & 66.0 & 63.5 & 112.6 & 108.8 & 15.8 & 13.9 & 2.35 & 2.5 & 6.15 & 5.73 & 18.4 & 17.9 & 1.0 & 1.0 \\
\hline 4 & $\begin{array}{c}\text { P-96 } \\
\text { UZPITI } \\
103)\end{array}$ & 20 & 5 & 65.0 & 60.0 & 113.0 & 111.1 & 16.1 & 14.5 & 2.9 & 2.8 & 6.0 & 5.4 & 18.3 & 17.6 & 1.15 & 0.93 \\
\hline & Avera & & & 66.0 & 61.2 & 111.0 & 108.3 & 16.0 & 14.65 & 2.9 & $\mathbf{3 . 0}$ & 5.6 & 5.2 & 17.8 & 16.9 & 0.9 & 0.82 \\
\hline
\end{tabular}

projects to bring the quality of cotton seeds in

The results of the above analyze show that mechanically damaged seeds germinate in the laboratory and in the field and develop as normal seeds.

\section{CONCLUSION}

In summary, in accordance with the requirements of the State Standards Oz DSt 663: 2017, the above indicators are being studied in the Republic, comparing them with the requirements of the International Seed Quality Control Association (ISTA) for seeds. Today, scientists, researchers and doctoral students of the Laboratory of Cotton Seed and Seed Research at the Research Institute of Cotton Breeding, Seed Production and Agrotechnology need to accelerate research in the framework of innovative and practical line with international standards. In addition, the issues raised above are considered to be one of the most important tasks in the development of the seed system today. We believe that it is time to make significant changes to the normative requirements and methods used with a scientific approach.

\section{REFERENCE}

1. Kozubaev Sh.S., Mamaraximov B.I. "Factors for improving cotton seed production" // - Monograph. - Tashkent. 2013. $-22 \mathrm{p}$.

2. Kozubaev Sh.S., Turakulov K. "Development of seed production and international cooperation" // "Agriculture of Uzbekistan" magazine. - Tashkent. 2013. - №11.- 19 p. 
Doi: https://doi.org/10.37547/tajabe/Volume02Issue09-05

3. Turabxodjaeva M., Kozubaev Sh., Abduvoxidov G. "The role of improving the state standards of the republic in improving the quality of seeds of agricultural crops" // Proceedings of the international scientific-practical conference "Current trends in selection, seed production and agrotechnology of field crops" PSUEAITI. Part 1.- Tashkent. 15-16 December 2016. p. -346-349.

4. TurabkhodjaevaM, KozubaevSh, Egamberdiev $R$ "The role of standards in seed production and seed production" // "Agriculture of Uzbekistan" J. Toshkent.№2 son., -2014. 33 p. 